\title{
Preface: Special Section on Ryan LaMothe
}

\author{
Nathan Carlin ${ }^{1}$
}

Published online: 4 September 2015

(C) Springer Science+Business Media New York 2015

It is my pleasure to introduce this special section on the recent work of Ryan LaMothe.

Educated at the United States Military Academy at West Point, the University of Notre Dame, and Vanderbilt University, LaMothe is currently a professor of pastoral care and counseling at Saint Meinrad School of Theology. In this position, LaMothe organized and administered the Pastoral Counseling Internship Program at the Louisville Family Counseling Center, and he developed, in collaboration with others, the Certificate in Supervision Program in Pastoral Care and Homiletics for St. Meinrad's Continuing Education Department. He also serves as the editor of Sacred Spaces: The E-Journal of the American Association of Pastoral Counselors. And, he has served on the editorial boards of both Pastoral Psychology and Journal for Pastoral Theology.

Prior to undertaking studies at Notre Dame, LaMothe served in the United States Army as battery commander, executive officer, and battalion staff officer from 1978 to 1984, which included a two-year command of a 150-person NATO combat unit. As a battery commander, he was responsible for all aspects of unit administration, training, maintenance, logistics, discipline, and morale. In this capacity, he received a number of awards: Ranger, Airborne, Meritorious Service Medal, Army Commendation Medal, and National Defense Service Medal. While at Notre Dame, and for three years following, LaMothe served as a hospital chaplain at Memorial and St. Joseph's Hospitals, South Bend, Indiana, which included six units of Clinical Pastoral Education as well as supervision of ministry students.

LaMothe's scholarship, like his educational background, is distinctive - this is why the journal is dedicating a special place to his work-in that his writing integrates psychoanalytic theory and political critique in pastoral theology. Indeed, he is one of the very few scholars writing in the area of pastoral theology/psychology, economics, and politics. While he has also written (and will continue to write) in psychology of religion and about clinical issues, his turn toward macro political and economic structures and systems occurred, as he disclosed to me, "around the time George W. Bush was elected to the presidency by the Supreme Court." LaMothe added: "I felt a need to shift my focus from strictly clinical and psychology of

Nathan Carlin

Nathan.Carlin@uth.tmc.edu

1 McGovern Center for Humanities and Ethics, The University of Texas Medical School, 6431 Fannin Street JJL 410, Houston, TX 77030, USA 
religion issues to these other realities of human hope and suffering. These and other articles are my way of working toward a political pastoral theology."

LaMothe has read extensively in theory as well as in the news. And, as these essays demonstrate, he writes beautifully and clearly. He is the author of four books (LaMothe 2001, 2005, 2009, 2013) and over 100 journal articles, as well as over a dozen book reviews. Currently, he is writing a book on political pastoral theology. This section of the journal includes four of his articles, all of which are new:

(1) "Just War: A Pastoral Analysis of the Hidden Violence of State-Corporate Capitalism";

(2) "Plutocratic Fears and Fantasies: Projective Identification and Enactment in a Market Society";

(3) "The Colonizing Realities of Neoliberal Capitalism"; and

(4) "Is Capitalism Corrupting Christianity?"

A few words about each of these interlocking essays are in order. In "Just War: A Pastoral Analysis of the Hidden Violence of State-Corporate Capitalism," LaMothe examines a form of "occult violence" - that is, a hidden form of violence in contemporary American culture - that is rooted in class warfare. LaMothe here defines "care" both theologically and politically, and by invoking the "just war" tradition of Roman Catholicism LaMothe subversively offers constructive ways for pastors, theologians, churches, and communities to resist this violence. In "Plutocratic Fears and Fantasies: Projective Identification and Enactment in a Market Society," LaMothe continues this analysis, but here he creatively invokes the work of psychoanalyst Melanie Klein and specifically her notion of "projective identification." In "The Colonizing Realities of Neoliberal Capitalism," LaMothe employs the notion of "colonization" as a heuristic device to analyze the psychosocial dynamics of neoliberal capitalism. And, in "Is Capitalism Corrupting Christianity?" LaMothe argues that the rise of capitalism as a dominant social imaginary in the United States corrupts both Christian theology as well as social relations within the church.

Readers may or may not agree with LaMothe's personal politics, but, in either case readers will be challenged by his writings.

\section{References}

LaMothe, R. (2001). Revitalizing faith through pastoral counseling. Nashville: Abingdon.

LaMothe, R. (2005). Becoming alive: Psychoanalysis and vitality. New York: Routledge Press.

LaMothe, R. (2009). Heresies of the heart: The development of emotional wisdom. Mahwah: Paulist Press.

LaMothe, R. (2013). Missing us: Re-envisioning psychoanalysis from the perspective of community. Lanham: Jason Aronson. 